\title{
STRATEGI KETERBUKAAN DIRI OLEH PENDAMPING KEPADA ANAK-ANAK KORBAN KEKERASAN SEKSUAL DI SURAKARTA
}

\author{
Azis Arouf \\ Program Studi Ilmu Komunikasi, Fakultas Komunikasi dan Informatika, \\ Universitas Muhammadiyah Surakarta, Kabupaten Sukoharjo, Jawa Tengah. \\ Email: azisarouf18@gmail.com \\ Vinisa Nurul Aisyah \\ Program Studi Ilmu Komunikasi, Fakultas Komunikasi dan Informatika, \\ Universitas Muhammadiyah Surakarta, Kabupaten Sukoharjo, Jawa Tengah. \\ Email:Vna409@ums.ac.id
}

\begin{abstract}
Article Info
Article History Received $11 \mathrm{Apr}$ 2020

Revised 03 Oct 2020 Accepted 04 Oct 2020
\end{abstract}

\begin{abstract}
The purpose of this research is to understanding the strategy of self-disclosure conducted by companion of Yayasan Kakak Surakarta to children's sexual abuse victim. Selfdisclosure by companion to children's sexual abuse victim be used to resolve case of children's sexual abuse and rehabilitations process of victim. The type of research is descriptive and qualitative with determine the informant use purpossive sampling. The technique data collection use indepthinterview and observation. Data validity using data triangulation. The results of this research is companion from Kakak Foundation Surakarta has different strategy at each area self-disclosure. Open area, companion use strategy that collaboration with another affairs and sharing tasks between companions from Kakak Foundation based on victim data. Hidden area companion use empathy to rising up the confidence and give pleasent feel for victim to reveal the sexual abuse incident. Blind area companion use strategy give powerfull respons to children' sexual abuse victim in order to tell the information that in point of fact they don't know about. Meanwhile in unknown area constitute area that can not be reveal because that is about the victim destiny in the future after the case resolved.
\end{abstract}

Keyword : Companion, Self-Disclosure, Sexual Abuse, Strategy. 


\begin{abstract}
Abstrak. Penelitian ini bertujuan untuk mengetahui bagaimana strategi keterbukaan diri yang dilakukan oleh pendamping di Yayasan Kakak Surakarta kepada anak-anak korban kekerasan seksual. Keterbukaan diri oleh pendamping kepada anak-anak korban kekerasan seksual digunakan untuk menyelesaikan kasus kekerasan seksual pada anak dan proses rehabilitasi korban. Jenis penelitian ini adalah penelitian deskriptif kualitatif dengan penentuan informan dengan teknik purposive sampling. Teknik pengumpulan data menggunakan indepth-interview dan observasi. Validitas data menggunakan triangulasi data. Hasil penelitian ini ialah pada proses pengungkapan diri anak-anak korban kekerasan seksual, pendamping menggunakan strategi yang berbeda di setiap area. Pada open area, pendamping menggunakan strategi bekerja sama dengan pihak luar dan membagi tugas pendampingan antar tim pendamping berdasarkan data korban. Pada hidden area, pendamping menggunakan empati untuk membangun kepercayaan dan memberikan rasa nyaman pada korban untuk mengungkapkan kejadian kekerasan seksual yang mereka alami. Pendamping juga bekerja sama untuk mengungkap hidden area korban. Pada blind area, pendamping menggunakan strategi memberikan respons yang maksimal agar anak-anak korban kekerasan seksual mau menceritakan informasi bahkan yang mereka tidak mengerti. Sementara pada. unknown area merupakan area yang tidak dapat digali, dalam hal ini nasib korban di masa depan setelah kasus terselesaikan.
\end{abstract}

Kata Kunci : Kekerasan Seksual, Keterbukaan diri, Strategi, Pendamping.

\section{PENDAHULUAN}

Fenomena kekerasan seksual pada anak yang terus berlangsung hingga saat ini merupakan hal yang sangat mengkhawatirkan. Dari tahun ke tahun, jumlah kasus kekerasan seksual bertambah sangat signifikan (Alfons, 2019). Oleh karena itu, perlindungan bagi anak dari berbagai tindakan kekerasan pada anak khususnya kekerasan seksual harus dihindarkan demi proses perkembangan anak. Dikutip dari detik.com (Ikhsanudin, 2019), Lembaga Perlindungan Saksi dan Korban (LPSK) mencatat bahwa jumlah kekerasan seksual pada anak meningkat dari 2016 sejumlah 25 kasus, 81 kasus pada 2017, dan 206 kasus pada di 2018. Data ini menunjukkan bertambahnya jumlah kekerasan seksual pada anak tiap tahun.

Kasus-kasus kekerasan seksual telah terekspos oleh media massa, salah satunya kasus Andri alias Emon pada 2014 yang menyodomi anak di bawah umur dengan menjanjikan korbannya diberi uang atau jajanan. Jumlah anak yang menjadi korban Emon diperkirakan 114 anak dengan rentang usia 6 sampai 13 tahun (Johan Fatzry, 2014). Dalam banyak kasus, anak yang menjadi korban kekerasan seksual sulit menceritakan apa yang mereka alami, dan enggan memberitahukan kepada orang lain. Ini karena hal tersebut dianggap pribadi dan memalukan. Akibatnya, penanganan terhadap kekerasan anak tidak mudah dilakukan. Inilah yang melatarbelakangi 
beberapa organisasi sosial untuk membantu penanganan kekerasan anak seperti Yayasan Kakak di Surakarta.

Yayasan Kakak berdiri sejak 23 Juli 1997 sebagai bentuk perhatian sekelompok orang yang mempunyai kepedulian terhadap permasalahan yang dialami oleh anak-anak dan remaja. Salah satu tugas Yayasan Kakak adalah melakukan rehabilitasi anak korban kekerasan seksual agar mereka dapat pulih kembali dari trauma yang mereka alami dan dapat berbaur kembali dengan lingkungan sekitarnya (Yayasan Kakak, 2015). Di yayasan tersebut, para korban akan mendapatkan program-program yang disajikan pendamping di Yayasan Kakak agar pulih dari pengalaman traumatik yang dialami.

Pendamping di Yayasan Kakak Surakarta berjumlah 7 orang yang terdiri dari 1 laki-laki dan 6 perempuan. Pendamping merupakan ahli di bidangnya baik pada aspek hukum atau advokasi maupun rehabilitasi bagi korban. Di Yayasan Kakak, mekanisme penanganan kasus kekerasan seksual dapat melalui dua jalur. Pertama, Yayasan Kakak sendiri mencari korban kekerasan yang perlu dibantu yang berasal dari berbagai laporan masyarakat. Kedua, pihak korban mengajukan pendampingan bagi korban.

Dalam penanganan kasus kekerasan seksual, diperlukan komunikasi interpersonal yang baik antara pendamping dengan korban kekerasan seksual. Menurut Devito (Handayani, 2017), komunikasi interpersonal sebagai penyampaian pesan yang dilakukan oleh satu orang ke orang lain atau suatu kelompok dan berpeluang mendapatkan suatu feedback. Komunikasi interpersonal ini biasa digunakan oleh Yayasan Kakak untuk menjalin hubungan kedekatan dengan anak-anak korban kekerasan seksual agar mereka dapat mudah terbuka dalam menceritakan kejadian yang mereka alami.

Menurut Devito (2011), selfdisclosure memiliki beberapa manfaat antara lain perspektif yang baru mengenai pengetahuan diri sendiri sehingga kita dapat memahami diri kita secara mendalam, kemampuan mengatasi kesulitan khususnya pada perasaan bersalah, efisiensi komunikasi dalam memahami pesan yang disampaikan oleh orang lain, kedalaman hubungan antarindividu yang artinya kita dapat lebih percaya kepada seseorang saat kita mengungkapkan diri kita.

Selain manfaat pengungkapan diri yang dijelaskan Devito (2011), Wood (2014) juga menyebutkan risiko pengungkapan diri yang akan dialami seseorang, yakni kemungkinan mendapatkan penolakan orang lain jika kita melakukan pengungkapan diri, perasaan tidak nyaman, dan membuat kita berpikir bahwa kita merendahkan diri kita sendiri seolah kita tidak akan diterima oleh orang lain.

Teori Self disclosure disebut juga Johari Window atau Jendela Johari yang berasal dari nama penemunya, Joseph Lutf dan Harrington Ingham. Konsep Johari Window, menurut Rakhmat (2018), menjelaskan dan memahami interaksi interpersonal yang memiliki empat kuadran antara lain area terbuka (open area), area buta (blind area), area tersembunyi (hidden area), area tidak dikenal (unknown area) yang terbentuk dari persimpangan antara pengetahuan diri dan pengungkapan diri untuk menjelaskan tentang pribadi seseorang seperti ditunjukkan gambar 1. 


\begin{tabular}{|l|l|}
\hline 1. Open Area & 2. \\
\hline 3. Hidden Area & 4. Unknown Area \\
\hline
\end{tabular}

Gambar 1. Johari Window

Penelitian Yanuar \& Pratiwi (2019) menunjukkan bahwa korban kekerasan seksual memiliki tingkat keterbukaan diri yang rendah sebab memiliki ruang hidden yang luas. Berbeda dengan penelitian tersebut yang fokus pada keterbukaan diri korban pelecehan seksual dengan orang tuanya, penelitian ini melihat bagaimana keterbukaan diri korban pelecehan seksual dengan pendamping sebagai salah satu langkah penyelesaian permasalahan baik secara hukum dan psikologis korban. Namun, penelitian ini memiliki kesamaan dalam aspek self-disclosure atau keterbukaan diri. Ia merupakan suatu proses keterbukaan diri mengenai suatu informasi tentang hal pribadi. Informasi tersebut bisa berupa suatu hal tentang pengalaman pribadi, perasaan, impian, ketakutan dan lain-lain (Mahardika \& Farida, 2019).

\section{METODE}

Penelitian ini merupakan penelitian kualitatif deskriptif. Riset kualitatif dapat menjelaskan suatu fenomena secara mendalam karena riset ini lebih mengutamakan kualitas data daripada kuantitasnya (Kriyantono, 2006). Tujuan riset kualitatif ini juga untuk melakukan penafsiran terhadap realitas sosial atau fenomena sosial yang akan diteliti (Pujileksono, 2015). Jenis metode ini dipilih sebab sesuai dengan fokus penelitian ini, yaitu strategi keterbukaan diri atau self-disclosure antara pendamping dengan anak korban kekerasan seksual di Yayasan Kakak Surakarta.

Informan dalam penelitian ini adalah pendamping di Yayasan Kakak Surakarta. Populasi yang ada di Yayasan Kakak Surakarta berjumlah 7 orang yang terdiri dari 6 pendamping wanita dan 1 pendamping laki-laki. Sampel atau informan yang diteliti menggunakan purposive sampling. Teknik sampling ini dipilih dengan maksud dan tujuan tertentu karena sampel atau informan memiliki dan dapat memberikan informasi yang diperlukan untuk kepentingan penelitian ini (Pujileksono, 2015). Dalam purposive sampling, ciri-ciri dan kriteria sampel atau informan yang diteliti ditentukan oleh peneliti dan disesuaikan dengan fokus penelitian. Kriteria tersebut antara lain: berdasarkan jenis kelamin pendamping di Yayasan Kakak Surakarta; dan berdasarkan durasi menjadi pendamping di Yayasan Kakak Surakarta.

Pertanyaan yang digunakan untuk wawancara mendalam diberikan sesuai tema penelitian ini yang berkaitan dengan komunikasi interpersonal dan selfdisclosure. Pertanyaan bebas juga ditanyakan dalam wawancara mendalam untuk mendapatkan data pendukung atau data sekunder dengan instrumen penelitian pedoman wawancara. Observasi secara langsung juga dilakukan oleh peneliti untuk mendapatkan data pendukung atau data sekunder. 
Terkait validitas data dalam penelitian ini, peneliti menggunakan triangulasi data. Pada dasarnya, triangulasi data digunakan agar fenomena yang diteliti dapat dipahami dengan baik dan dapat diperoleh kebenaran penelitian jika di dekati dengan berbagai sudut pandang (Pujileksono, 2015). Triangulasi data dilakukan dengan cara membandingkan data dari informan yang berbeda. Dalam penelitian ini, peneliti membandingkan data dari informan satu dengan lainnya serta membandingkan dengan artikel jurnal rujukan.

Penelitian ini menggunakan analisis data interaktif dengan 3 tahapan. Pertama, reduksi data, peneliti melakukan reduksi data dengan memilih dan memfokuskan data-data pokok sesuai tema dan teori penelitian. Kedua, tahap penyajian data dengan menyajikan data berupa koding yang berasal dari transkip wawancara yang dikategorisasikan sesuai dengan temuan dan teori Johari Window. Ketiga, kesimpulan serta verifikasi. Pada tahap ini, peneliti menarik kesimpulan dari data dan Teori Johari Window.

\section{HASIL DAN PEMBAHASAN}

Penelitian ini dilakukan di Yayasan Kakak Surakarta Jl. Flamboyan Dalam No.1, Purwosari, Laweyan, Surakarta pada rentang waktu bulan November sampai dengan Desember 2019. Informan penelitian berjumlah tiga orang pendamping di Yayasan Kakak yang terdiri dari 2 orang perempuan dan 1 orang lakilaki. Proses wawancara dilakukan dengan diawali obrolan biasa dan diikuti dengan memberikan pertanyaan sesuai pedoman wawancara secara fleksibel agar informan dapat menyampaikan jawaban pertanyaan dengan nyaman dan mendalam pada proses wawancara dengan pendamping di Yayasan Kakak. Uraian hasil penelitian akan dipaparkan dengan menggunakan dasar teori Self-Disclosure Johari Window.

\section{Open Area}

Rakhmat (2018) mendefinisikan open area sebagai area terbuka yang dapat diakses oleh orang lain, misalnya, data diri korban kekerasan seksual. Dalam penelitian ini, open area merupakan daerah terbuka yang berisi tentang informasi anak-anak korban kekerasan seksual di Yayasan Kakak Surakarta yang berupa identitas diri korban. Identitas anak-anak korban kekerasan seksual tersebut didapatkan melalui korban sendiri maupun pihak luar seperti polisi dan orang tua korban. Identitas korban juga dijadikan pendamping sebagai data awal proses pendampingan di Yayasan Kakak Surakarta.

\section{Identitas Diri Berasal dari Banyak Sumber}

Informan menyebutkan identitas diri korban kekerasan seksual yang didapatkan pendamping berasal dari banyak sumber. Identitas tersebut meliputi nama, umur, alamat anak-anak korban kekerasan seksual untuk kebutuhan pendampingan di Yayasan Kakak Surakarta.

"Informasi bisa didapat dari
keluarga korban jika kasusnya
korban yang meminta bantuan
langsung kepada Yayasan Kakak
untuk membantu menyelesaikan
atau dari polisi karena polisi
yang menghubungi kami untuk
membantu perlindungan dan
membimbing anak selama proses
hukum berjalan (Wawancara
Informan 1, 20 Desember 2019)"

"Informasi bisa didapat dari keluarga korban jika kasusnya korban yang meminta bantuan langsung kepada Yayasan Kakak atau membantu menyelesaikan atau dari polisi karena polisi yang menghubungi kami untuk membantu perlindungan dan membimbing anak selama proses hukum berjalan (Wawancara Informan 1, 20 Desember 2019)" 
Hal yang sama juga dikatakan oleh informan kedua bahwa identitas diri anakanak korban kekerasan seksual didapatkan melalui orang tua korban sendiri maupun pihak luar seperti polisi, Pusat Pelayanan Terpadu (PPT). Hal ini dikarenakan kondisi korban yang masih anak-anak ratarata berusia di bawah 5 tahun.

"Biodata, ada yang sendiri ada yang dari orang tua, karena untuk yang di bawah 5 tahun susah kan ya nama orang tuanya aja kadang mereka susah, jadi memang harus orang tuanya tapi kalau yang udah bisa membaca ya dari mereka sendiri" (Wawancara informan 2, 18 November 2019)

Pendamping juga melakukan cross check data korban yang diterima dari pihak luar dengan anaknya langsung agar data yang masuk ke Yayasan Kakak benar-benar valid seperti yang dijelaskan oleh informan kedua berikut.

"Aku lebih banyak ketemu langsung dulu, misalnya kalo akhirnya kebutuhan kantornya ya misalnya untuk menginput kan nama jadi harus lihat data diri korban serta KK dan lain-lainnya habis itu ngobrol lagi sama anaknya" (Wawancara informan kedua, 18 November 2019)

Informan kedua juga menjelaskan bahwa data korban didapatkan dengan mudah dari pihak luar yang bekerjasama dengan Yayasan Kakak antara lain dari pihak keluarga, Polisi maupun Pusat Pelayanan Terpadu. Jika ada kasus, mereka akan menghubungi Yayasan Kakak untuk melakukan proses pendampingan terhadap anak-anak korban kekerasan seksual. Dengan demikian, Yayasan Kakak dengan pihak luar saling membantu untuk menangani kasus anak-anak korban kekerasan seksual. Dengan saling memberikan data-data anak korban kekerasan seksual, menjadikan kasus dapat teratasi dengan lancar.

\section{Identitas Diri Digunakan Sebagai Data Awal Proses Pendampingan}

Dalam menjalin hubungan dengan anak-anak korban kekerasan seksual, pendamping di Yayasan Kakak menggunakan identitas dalam open area sebagai data awalan dalam pembagian jobdesk pendamping. Informan ketiga mengatakan bahwa biasanya pembagian tersebut berdasarkan kondisi korban yang mengalami trauma. Informan kedua juga menjelaskan bahwa dirinya tidak mendampingi korban anak-anak perempuan yang menuju remaja sekitar usia 13 tahun ke atas. Ini karena ia membatasi agar tidak terjadi hal-hal yang tidak diinginkan saat proses pendampingan. Hal tersebut dilakukan karena informan ketiga menghindari kontak langsung dengan korban agar korban tidak bertindak hal negatif dan tidak agresif kepada informan.

Setelah dilihat biodata anak korban, pendamping melakukan pendekatan dengan cara mengobrol atau bermain bersama yang nantinya dapat diketahui bahwa anaknya akan memilih pendamping yang nyaman buat dia. Tahapan ini merupakan rangkaian awal proses pendampingan bidang pemulihan psikis anak di Yayasan Kakak oleh pendamping. Dengan begitu, diharapkan dapat cepat pulih dari trauma yang dialami. Temuan dalam open area menyatakan, informasi data diri seperti nama, alamat, jenis kelamin dan usia anakanak korban pelecehan seksual menjadi sebuah data awalan dalam proses pembagian pendamping. Open area yang didapatkan dari berbagai sumber ini biasanya juga digunakan untuk menentukan siapa pendamping yang cocok 
bagi korban untuk menangani kasus tersebut. Dalam konsep Johari Window, open area ini merupakan area awal yang menunjukkan bahwa komunikasi yang baik dan kerja sama antar individu dapat terjalin (Osmanoğlu, 2019).

Pada proses pendampingan, meski pendamping sudah mengetahui sebagian besar informasi tentang korban, tapi biasanya pendamping tetap menanyakan pada anak-anak untuk melakukan cross check agar data yang masuk ke Yayasan Kakak benar-benar valid. Ini sekaligus dilakukan untuk menjalin hubungan senatural mungkin dengan korban. Probosiwi \& Bahransyaf (2015) mengatakan bahwa diperlukan kerja sama dan pihak luar seperti pemerintahan dan lembaga terkait lainnya yang peduli terhadap kekerasan seksual pada anak untuk melaksanakan program perlindungan dan penyelesaian kasus kekerasan seksual pada anak.

\section{Hidden Area}

Hidden Area merupakan daerah tersembunyi yang berisi informasi yang sangat pribadi dan orang lain tidak boleh tahu tentang informasi tersebut. Pada penelitian ini, informasi tersebut dapat berupa pelaku, tempat kejadian, detail kejadian serta informasi tentang kejadian pelecehan seksual.

Pendamping di Yayasan Kakak
Surakarta dalam penelitian ini
menggunakan beberapa strategi untuk
mengungkap hidden area anak-anak
korban kekerasan seksual antara lain
pendamping berusaha berada di pihak
korban, pendamping berusaha menjadi
teman sebaya korban, dan juga
pendamping dalam proses ini
memosisikan diri sebagai volunteer. Hal
tersebut berperan besar dalam

pengungkapan hidden area pada anakanak korban kekerasan seksual tersebut.

\section{Pendamping Berusaha Berada di Pihak Korban}

Pendamping berusaha berada di pihak korban dengan menggunakan katakata yang persuasif bahwa pendamping merupakan teman korban dan akan selalu ada untuk korban. Contoh kata-kata yang disampaikan oleh pendamping kepada anak-anak korban kekerasan seksual seperti "ga usah takut, mbak akan bantu kamu nyelesain semua", "mbak tu ada di pihak kamu jadi jangan takut", "kamu tu ngga salah, masnya itu yang salah jadi ga usah nangis kamu ngga kenapa-kenapa kok".

Informan kedua mengatakan bahwa sebagai pendamping dirinya harus memosisikan diri berada di pihak korban. Bagaimanapun keadaan korban, ia akan senantiasa berada di pihaknya. Menurutnya, dengan berada di pihak korban, korban akan lebih mudah untuk menceritakan apa yang terjadi padanya. Anak-anak juga akan sangat merasa nyaman untuk bercerita dengan pendamping tentang apa saja yang telah mereka alami selama ini. Anak-anak korban kekerasan dapat mengungkapkan segala hal yang telah mereka sembunyikan selama ini, dan informasi tersebut dapat diterima oleh pendamping untuk di lakukan proses selanjutnya. Apakah untuk rehabilitasi korban mendatang ataupun untuk bantuan hukum mereka?

Hal yang sama juga dikatakan oleh informan ketiga. Menurutnya, pendamping selalu ada di pihak anak korban kekerasan seksual tersebut walau bagaimanapun kondisi korban. Dalam kaitan ini, Nasofa et al., (2016) yang meneliti pendampingan terhadap anak binaan mengemukakan bahwa asesmen 
pendamping terhadap anak jalanan yang baru bergabung dengan Yayasan bermaksud menjajaki karakter, emosi, dan kebiasaan anak jalanan.

\section{Berperilaku Seperti Teman Sebaya}

Pendamping anak-anak korban kekerasan seksual di Yayasan Kakak berperilaku seperti teman sebayanya agar mereka merasa tidak ada gap antara dirinya dengan pendamping. Menjadi teman sebaya juga akan membuat korban lebih nyaman saat bercerita dengan pendamping. Salah satu pendamping, informan ketiga, mengatakan ia mulai dengan mengikuti cara korban berbicara dan menggunakan bahasa seperti yang mereka gunakan sehari-hari. Hal lain yang dilakukan pendamping dengan anak-anak korban kekerasan seksual, yakni bermain bersama. Bermain dengan korban bisa menjadi suatu cara agar korban nyaman dengan pendamping di Yayasan Kakak sendiri.

Tiara \& Pratiwi (2018) dalam penelitiannya mengungkapkan bahwa pendamping memosisikan diri sebagai teman korban agar korban dengan nyaman melakukan percakapan dengan respons ke arah yang lebih personal lagi. Nasofa et al., (2016) mendapatkan temuan penelitian bahwa tugas pendamping saat mendampingi anak binaannya sangatlah beragam. Mereka harus bisa menciptakan suasana nyaman bagi anak jalanan yang dibina sehingga anak binaan ini mau terbuka tentang masalah yang sedang dihadapi dan terbuka untuk melakukan perubahan dalam hidupnya.

\section{Pengalaman Pendamping Korban Mendapatkan Hidden Area}

Proses mendapatkan data hidden area tiap pendamping dan korban berbeda-beda tergantung situasi dari pendamping maupun anak-anak korban kekerasan seksual itu sendiri. Menurut para informan, mendapatkan data hidden area korban tidaklah susah karena proses tersebut dilakukan dengan sukarela bagi para pendamping di Yayasan Kakak itu sendiri. Hidden area dapat ditemukan oleh pendamping dengan cara menjembatani anak-anak korban seksual untuk mengingat hal-hal kecil yang terjadi saat pelecehan itu terjadi, dan itu membutuhkan waktu yang lama.

"Pemeriksaan anak itu bisa dari jam 8 pagi sampai jam 5 sore, dan itu gak cukup sehari, makanya, biasanya udah di urutin dulu. Biasanya kalau udah ke kakak, tak suruh ngasih tanggal untuk membantu mengingat di hari itu. Kamu pakai seragam apa kalau sekolah kan ingat tuh, misal kalau pakai pramuka berarti jumat, berarti kalau pas pakai batik itu hari apa silahkan di ingat-ingat. [Ini] Biar mereka ingat kronologisnya biar runtut, biar ceritanya enak" (Wawancara informan kedua, 18 November 2019)

Sementara itu, pengalaman informan ketiga dalam melakukan pendampingan terhadap anak-anak korban kekerasan seksual menyatakan bahwa hidden area terkadang sulit ditemukan sebab kondisi korban yang defensif. Hal ini membuatnya harus melakukan pendekatan berkali-kali.

Kondisi hidden area yang merupakan tindak kejahatan pelecehan seksual yang dialami anak-anak membuat informasi tersebut sering kali ditutupi oleh korban itu sendiri. Dalam menghadapi persoalan ini, pendamping biasanya memanfaatkan pihak lain. Pendamping biasanya melakukan cross check ke 
berbagai sumber informasi yang dibutuhkan mengenai korban mulai dari pihak kepolisian dan ke pihak psikolog.

Dalam banyak kasus, anak-anak menyimpan rahasianya menjadi korban kekerasan seksual dan menutupinya dengan bersikap manis dan patuh terhadap orang lain, dan berusaha agar dirinya tidak menjadi pusat perhatian (Sari et al., 2015). Pengungkapan hidden area yang kemudian menjadi cara yang efektif untuk membangun komunikasi yang efektif dan menumbuhkan rasa saling percaya (Osmanoğlu, 2019).

Karakteristik kerja di Yayasan Kakak yang bersifat relawan sangat berperan besar dalam pengungkapan hidden area. Pendamping berusaha untuk selalu berada di pihak anak-anak, berbicara mengikuti pola pikir anak-anak dan mencurahkan kepedulian pada korban sampai korban merasa nyaman untuk membicarakan apa yang mereka sembunyikan. Dengan kata lain, pendamping menggunakan empatinya untuk menggali hidden area. Wood (2014) menyatakan komunikasi dengan menggunakan empati merupakan salah satu strategi yang menekankan pada aspek penerimaan.

Dalam penelitian lain, Tiara \& Pratiwi (2018) mengemukakan bahwa pendamping pada kasus perkosaan yang didampingi oleh Legal Resource Centre untuk Keadilan Jender dan Hak Asasi Manusia (LRC-KJHAM) Semarang juga melakukan hal yang sama. Pendamping yang memosisikan diri menjadi teman korban, dapat membuat korban merasa nyaman dalam melakukan percakapan dan mendapat respons percakapan ke arah yang lebih personal lagi.

Keputusan untuk mengungkapkan hal yang ada dalam diri individu menjadi sesuatu yang dilematis bagi manusia. Menurut DeVito (Rajab et al., 2018), pengungkapan diri akan menyebabkan penolakan oleh pribadi dan sosial maupun kesulitan intrapribadi yang menyebabkan kecemasan dan ketakutan dari dalam diri. Suyono (2019) mengatakan bahwa banyak korban kekerasan merasa malu telah menjadi korban karena dianggap sebagai aib dalam keluarga.

Dalam kasus kekerasan seksual pada anak ini, korban juga mengalami hal yang sama seperti yang telah diungkapkan oleh DeVito sebelumnya bahwa anak korban kekerasan seksual mengalami penolakan diri karena korban merasa bahwa dirinya menyebabkan aib dalam keluarga. Ini membuat korban merasa cemas dan tidak berani mengakui bahwa dirinya telah mengalami kekerasan seksual. Sehingga mereka berusaha menutupi kejadian tersebut.

\section{Blind Area}

Blind Area merupakan daerah buta informasi terhadap diri sendiri namun orang lain mengetahui informasi akan hal tersebut. Dalam penelitian ini, blind area merupakan kondisi anak-anak korban kekerasan seksual khususnya terkait dengan dampak kejadian pelecehan seksual yang sulit dimengerti oleh anakanak.

Blind area yang merupakan suatu informasi dari anak-anak korban kekerasan seksual yang mana korban tidak tahu, tapi orang lain tahu tentang informasi kejadian tersebut. Dalam kasus ini, blind area pada anak merupakan respons korban ketika mendapat kekerasan seksual dari tersangka. Johari window menyebutkan blind area sebagai area ketidaktahuan akan diri sendiri (Osmanoğlu, 2019). Dalam penelitian ini, pendamping mengungkap blind area melalui pemberian feedback yang maksimal dalam penggalian informasi agar 
korban pelecehan seksual terus menceritakan informasi.

Penelitian ini menemukan bahwa pengalaman dan kegigihan pendamping dalam menggali informasi di blind area membutuhkan upaya maksimal. Kondisi korban dalam penelitian ini kebanyakan tidak mengetahui bahwa dirinya telah mengalami kekerasan seksual. Setelah mengetahui blind area, pendamping tidak melakukan upaya peningkatan self awareness pada anak-anak korban pelecehan seksual terkait dengan kasus yang menimpanya untuk menjaga kesehatan psikologis anak-anak. Noviana (2015) mengatakan bahwa jika anak-anak korban kekerasan seksual diceritakan kembali kejadian yang telah dialaminya dikhawatirkan akan menyebabkan dampak negatif bagi korban karena korban akan mengingat-ingat kembali kejadian yang telah ia alaminya.

Secara fisik pun, anak tidak mengerti jika mereka telah mendapatkan kekerasan seksual. Hal tersebut juga harus dibuktikan dengan hasil visum oleh pihak tenaga medis dan untuk keperluan data bukti pengajuan peradilan. Nafisah et al., (2015) mengatakan bahwa visum merupakan salah satu bukti yang standar penyidik untuk mengungkap kasus kekerasan seksual.

Hal ini tentu berbeda dengan apa yang ditawarkan dalam teori Johari Window. Dalam kajiannya, pengungkapan blind area dimaksudkan untuk meningkatkan self awareness agar ia mampu memahami lebih siapa dirinya dan apa yang menimpa dirinya dari sudut pandang orang lain. Wood (2014) juga mengatakan bahwa pengetahuan terhadap diri sendiri akan memahami diri sendiri dan penilaian terhadap diri sendiri dari sudut pandang konstruksi sosial.

Data blind area terkadang didapatkan melalui perantara orang tua korban dikarenakan korban tidak nyaman untuk bercerita langsung ke pendamping dengan menggunakan bahasa anak-anak agar anak nyaman untuk bercerita. Informan keduanya, misalnya, mengatakan, "Mbak cerita dong, Mama pengen di ceritain kaya gimana dokterdokterannya" (Wawancara informan 2, 18 November 2019).

Ada berbagai macam dampak yang ditimbulkan setelah terjadinya kekerasan seksual pada anak. Noviana (2015) menyebutkan berbagai macam dampak yang ditimbulkan antara lain dampak psikologis, dampak fisik dan dampak keluarga. Dalam dampak psikologis, anak akan mengalami antara lain dampak negatif, agresif, anti sosial, pasif, emosional dan apatis terhadap apa yang sedang mereka alami. Meskipun begitu, dampak ini akan berbeda pada setiap anak. Bahkan, anak-anak korban kekerasan seksual tidak merasa bahwa dirinya telah menjadi korban atau apatis terhadap apa yang telah mereka alami.

\section{Menjaga Blind Area pada Anak-anak Korban Kekerasan Seksual}

Ketika anak korban kekerasan seksual tersebut tidak mengetahui bahwa dirinya telah mengalami kekerasan seksual, tetap orang tuanya tidak diperbolehkan untuk memberi tahu kepada anaknya atas kejadian yang dialaminya. Informan 2 juga mengatakan bahwa menangis pun orang tua tidak boleh berada di depan si anak karena akan membuat bingung dan kondisi psikis anak tersebut malah goyah.

Setelah menggali apa yang telah dialami oleh korban, kejadian kekerasan seksual yang dialami oleh korban tidak boleh diceritakan lagi ke korban karena akan memberikan dampak negatif ulang terhadapnya. Noviana, (2015) mengatakan 
bahwa membicarakan apa yang dialami oleh anak-anak korban kekerasan seksual dikhawatirkan akan menambah dampak negatif pada korban karena korban akan mengingat ulang kejadian yang telah dialaminya.

Blind Area anak-anak korban kekerasan seksual juga dapat diketahui melalui cek fisik yang dilakukan oleh pendamping di Yayasan Kakak maupun pihak luar. Hal ini untuk mengetahui apakah benar anak tersebut telah mendapatkan kekerasan seksual dari orang lain. Nantinya, hasil dari bukti cek fisik akan dijadikan bahan untuk proses peradilan selanjutnya di ranah hukum. Informan 2 dalam hal ini mengatakan sebagai berikut.

"Sampai ada keputihan, sampai ada iritasi, pipisnya sakit, itu pasti ada sesuatu dari luar, dan bisa di lihat dari lingkungan dia, gerak geriknya dia pasti tetap ada kalau proses itu akhirnya di proses. Anak pasti tetap ada ketakutan dengan pelaku. Jadi, kalau anaknya sudah menyadari dia akan menyadari ketakutan dengan pelaku, "aku takut kok dengan Mas itu”, "Kenapa ?", "Ya takut aja". Nanti gitu dia baru cerita, oke berarti dia pelakunya."

Cek fisik ini harus dilakukan secepatnya oleh Yayasan Kakak atau pihak luar yang sedang bekerjasama dengan Yayasan Kakak agar hasil dari cek fisik ini masih bisa keluar dari kedokteran. Seperti pengalaman yang pernah dialami oleh Yayasan Kakak, luka yang dialami oleh anak-anak akan lebih cepat sembuh karena imun mereka masih sangat tinggi. Dalam wawancara, informan 2 menjelaskan jika cek fisik dilakukan melewati hari itu (hari kejadian), dikhawatirkan bukti cek fisik tidak akan keluar. Yayasan Kakak akan mengalami kesulitan dalam mencari bukti untuk menyelesaikan kasusnya di ranah hukum. Temuan penelitian ini sejalan dengan penelitian Lisdri (2018). Menurutnya, korban yang telah mengalami kekerasan seksual akan dilakukan cek kehamilan dan cek fisik atau visum yang didampingi oleh pihak kepolisian untuk kebutuhan bukti penindaklanjutan kasus kekerasan seksual pada anak.

\section{Unknown Area}

Unknown Area merupakan area yang orang tersebut tidak mengetahui informasi tentang dirinya sendiri. Orang lain juga tidak mengetahui informasi tentang orang tersebut. Dalam penelitian ini, unknown area merupakan ranah yang berada di luar kasus pelecehan seksual. Misalnya, berkaitan dengan masa depan antarkedua belah pihak. Dalam hal ini, baik pendamping atau korban tidak mengetahui bagaimana kondisi saat nanti menjalani kehidupan biasa di waktu yang akan datang.

Walaupun hubungan antara korban dengan pendamping kadang-kadang masih ada seperti jika ada acara di Yayasan Kakak, tapi hubungannya tidak sampai ke tahap personal korban seperti kehidupan mereka setelah di rehabilitasi di Yayasan Kakak. Informan ketiga, dalam hal ini, mengatakan, "Masih menjalin. Tapi kadang kalo dia kan masih ini ya masih di jalan lagi kayak biasanya yang ngamen gitu di jalan jalan" (Wawancara informan 3, 11 Desember 2019). Pendamping di sini hanya cukup tahu saja tentang apa yang telah korban lakukan di luar setelah pendampingan yang terpenting tidak melakukan tindakan yang berkaitan dengan kekerasan seksual setelah dari Yayasan Kakak. Prediksi masa depan terkait dengan anak-anak korban kekerasan seksual menjadi persoalan yang di luar penanganan Yayasan Kakak. Hal ini 
terjadi sebab yayasan Kakak merupakan yayasan yang fokus pada pendampingan kasus dan rehabilitasi korban saja.

Pada penelitian yang dilakukan oleh Yanuar \& Pratiwi (2019), inisial IM sebagai korban pelecehan seksual di Kuta Baro, Aceh Besar, tidak mengetahui apakah setelah kejadian ini ibunya akan peduli ataupun memerhatikan IM seiring berjalannya waktu setelah kejadian yang terjadi pada IM. IM pun juga tidak mengetahui bisakah dirinya menghadapi kehidupan selanjutnya pasca-kejadian pahit yang telah dia alami sebelum ini. Ibu dari IM menganggap bahwa IM setelah kejadian tersebut telah baik-baik saja, sudah mampu berinteraksi kembali dengan orang-orang di sekitarnya, dan sudah dapat beraktivitas kembali seperti sedia kala.

\section{KESIMPULAN}

Berdasarkan penelitian yang telah dilakukan oleh peneliti pada pendamping di Yayasan Kakak Surakarta ada beberapa strategi yang digunakan oleh pendamping dalam proses pengungkapan diri terhadap anak korban kekerasan seksual. Strategi pengungkapan diri yang dilakukan pendamping berbeda-beda di setiap area. Di open area, pendamping menggunakan strategi bekerja sama dengan pihak luar dan membagi tugas pendampingan antar tim pendamping berdasarkan data korban. Di hidden area, pendamping menggunakan empati untuk membangun kepercayaan dan memberikan rasa nyaman pada korban untuk mengungkapkan kejadian kekerasan seksual yang mereka alami. Pendamping juga bekerja sama untuk mengungkap hidden area korban.

Implikasi penelitian ini terutama pada lembaga yang berkaitan. Dalam penanganan kasus kekerasan seksual pada anak-anak untuk menerapkan komunikasi yang mengedepankan rasa empati serta saling bekerjasama baik pihak kepolisian, LSM dan pihak lain dalam penyelesaian kasus tersebut. Dari sisi akademik, penelitian setipe dapat dikembangkan dalam ranah yang lebih luas misalnya bagaimana proses adaptasi korban pelecehan seksual setelah kasus diselesaikan. Meskipun demikian, hasilhasil penelitian ini tidak menutup kemungkinan untuk menjadi model atau pembelajaran bagi pihak lain yang melakukan pendampingan, termasuk orang tua. Di sisi lain, karena kasus-kasus pelecehan seksual terus meningkat, adalah penting untuk memperluas penelitianpenelitian dalam kasus-kasus yang berbeda. 


\section{Daftar Pustaka}

AAlfons, M. (2019). LPSK: kasus kekerasan seksual pada anak meningkat tiap tahun. Detik News.

https://news.detik.com/berita/d4637744/lpsk-kasus-kekerasan-seksualpada-anak-meningkat-tiap-tahun\#

Devito, J. A. (2011). Komunikasi antar manusia (5th ed.). Tangerang: Karisma Publishing Group.

Handayani, M. (2017). Pencegahan Kasus Kekerasan Seksual Pada Anak Melalui Komunikasi Antar Pribadi Orang Tua Dan Anak. JIV-Jurnal Ilmiah Visi, 12(1), 67-80.

https://doi.org/10.21009/JIV.1201.7

Ikhsanudin, A. (2019). KPAI sebut kasus kekerasan seksual anak meningkat akibat pengaruh digital. Detik News. https://news.detik.com/berita/d4640789/kpai-sebut-kasus-kekerasanseksual-anak-meningkat-akibatpengaruh-digital

Johan Fatzry. (2014). Kejadian luar biasa kasus pedofil emon, 114 anak jadi korban. Liputan 6. https://www.liputan6.com/news/read/204 8164/kejadian-luar-biasa-kasus-paedofilemon-114-anak-jadikorban?utm_expid=.9Z4i5ypGQeGiS7 $\mathrm{w}$ 9arwTvQ.0\&utm_referrer=https $\% 3 \mathrm{~A} \% 2$ F\%2Fwww.google.com\%2F

Kriyantono, R. (2006). Teknik praktis riset komunikasi (1st ed.). Jakarta: Kencana Prenadamedia Group.
Lisdri, L. S. (2018). Perlindungan anak korban kekerasan oleh unit pelaksanaan teknis pusat pelayanan terpadu korban kekerasan perempuan dan anak (UPT PPT KKPA) kabupaten bantul. Jurnal Pndidikan Kewaraganegaraan Dan Hukum, 7(6).

Mahardika, R. D., \& Farida, F. (2019). Pengungkapan diri pada instagram instastory. Jurnal Studi Komunikasi, 3(1).

Nafisah, N. W., Padmomartono, S., \& Windrawanto, Y. (2015). Meningkatkan Kematangan Karir Remaja Melalui Teknik Problem Solving Berbantuan Media Mind Map. Jurnal Ilmiah Pendidikan, Sejarah, Dan Sosial Budaya Widya Sari, 17 (2).

Nasofa, A., Effendi, M., \& Nurhadi, N. (2016). Strategi pendampingan anak jalanan (studi kasus di jaringan kemanusiaan jawa timur). Jurnal Pendidikan Nonformal, 11(1). https://doi.org/10.17977/um041v11i1p17

Noviana, I. (2015). Kekerasan Seksual terhadap Anak: Dampak dan Penanganannya. Sosio Informa, 1(1).

Osmanoğlu, D. E. (2019). Expansion of the Open Area (Johari Window) and Group Work Directed to Enhancing the Level of Subjective Well-being. Journal of Education and Training Studies, 7(5), 76. https://doi.org/10.11114/jets.v7i5.4128

Probosiwi, R., \& Bahransyaf, D. (2015).

Pedofilia dan kekerasan seksual: masalah dan perlindungan terhadap anak. Sosio Informa, 1(1). 
Pujileksono, S. (2015). Metode Penelitian Komunikasi Kualitatif. Malang: Kelompok Intrans Publishing.

Rajab, M., Amalia, D. P., \& Harmin, S. (2018). Analisis komunikasi interpersonal keterbukaan diri pada penderita hiv/aids di kota kendari. Jurnal Ilmu Komunikasi UHO: Jurnal Penelitian Kajian Ilmu Komunikasi \& Informasi, 3(2).

http://ojs.uho.ac.id/index.php/KOMUNI KASI/article/view/5088

Rakhmat, J. (2018). Psikologi Komunikasi. Simbiosa Rekatama Media.

Sari, R., Nulhaqim, S. A., \& Irfan, M. (2015). Pelecehan Seksual Terhadap Anak. Prosiding Penelitian Dan Pengabdian Kepada Masyarakat, 2(1). https://doi.org/10.24198/jppm.v2i1.1323 0

Suyono, Y. . (2019). Perlindungan hukum bagi anak korban kekerasan psikologis di dalam rumah tangga dari orangtua. Lex Journal: Kajian Hukum Dan Keadilan, 3(1).
Tiara, S., \& Pratiwi, M. R. (2018). Proses pendampingan melalui komunikasi teurapetik sebagai upaya pemulihan psikologis korban perkosaan. Jurnal AnNida, 10(2).

https://ejournal.unisnu.ac.id/JKIN/article/ view/790

Wood, J. T. (2014). Interpersonal communication everyday encounters. Wadworth Publishing.

Yanuar, D., \& Pratiwi, C. S. (2019). The Secret Persona Korban Pelecehan Seksual (Komunikasi Interpersonal Antara Ibu dan Anak Korban Pelecehan Seksual di Kuta Baro, Aceh Besar). Warta ISKI, 2(02), 140-149. https://doi.org/10.25008/wartaiski.v2i02. 41

Yayasan Kakak. (2015). Yayasan kepedulian untuk anak surakarta. Yayasan Kakak. http://yayasankakak.org/ 